\title{
Benefits of Working in Pairs in Problem Solving and Algorithms - Action Research
}

\author{
By Soly Mathew Biju*
}

The purpose of this study is to examine the impact of peer tutoring program as compared to classroom tutoring on problem solving and algorithm development skills of higher education students in Computer Sciences. Peer tutoring has emerged as one of the most effective mechanisms of enabling learning and improving academic performance of students at all levels of education. It has since been put into practice by various institutions in a number of ways involving the tutor, the tutee and teachers or school administration who work together through a systematic process. Peer tutoring has emerged as one of the most effective mechanisms of enabling learning and improving academic performance of students at all levels of education. Primary research where selected students were trained and assigned peer tutees in the algorithms and problem solving class taught to undergraduates in the first semester. Students were placed in pairs. A pair consists of a peer tutor selected based on certain criteria and a tutee. The interesting aspect of this study is that it tests the impact of working in pairs had a positive impact on both on the tutor and the tutee.

Keywords: education, working in pairs, computer sciences, algorithm development, problem solving.

\section{Introduction}

With the world becoming increasingly competitive in all spheres, including education, it has become pertinent for educational institutions to incorporate newer, innovative and more effective ways of enabling learning for students. Not only is education becoming complex in terms of course content and curriculum, but increasing unemployment rate in most countries of the world is creating pressure on institutions to prepare students for academic and career success in a better way. A high dropout rate due to lack of real-world experience and inability to cope with coursework is one of the biggest challenges in academia today, especially in the stream of computer science education. Various modern mechanisms and strategies have been put into play to curb the dropout rate as well as to foster better academic performance of students, such as incorporating latest technology in classroom, eLearning, a stronger screening process of faculty, etc. and working in pairs is one of them. Peer tutoring is defined as a focused learning and interaction between students in the same class; one who is good at the subject becomes the 'tutor' while the student who needs help with the subject becomes the 'tutee' (Topping, Duran, \& Van Keer, 2016 , p. 10). This process of using students to tutor other students can take place during class timings as a group activity, or outside of class. The tutor

*Associate Professor, UOWD, UAE. 
focuses on an area which needs improvement or strengthening of the tutee. The National Education Association (NEA), an institution leading the cause of public education in the USA, strongly supports peer tutoring as it leads to better academic performance. The NEA advocates the use of same-age peer teachers as an equally effective substitute for regular class teachers, when it comes to explaining the course content (Chen \& Liu 2011). This system has been proven to be more successful than traditional classroom teaching because it provides a substantially higher amount of individual attention to each student as compared to classroom tutoring; and the tutees can also track their progress instantly. This method has proved the old saying that "to teach is to learn twice", since teachers learn more while teaching, as proven in a study conducted by the University of Dundee (Chen \& Liu, 2011).

According to Horan (2016), the main reason for the success of peer tutoring is that students feel more comfortable receiving instructions from other students than the teachers. Peer tutoring develops a focused communication channel and a better relationship between tutors and tutees. In a typical peer tutoring session, the tutor switches roles with the teacher with respect to explaining the lessons to the tutee; this not only helps the tutor develop his/her own understanding on the subject but also provides personalized attention to the tutee. However, Johnson (2016) the importance of student-student interaction is largely overlooked in present-day education. Not only does it help better academic performance, but it also enables socialization and healthy mental development of the students, as it contributes to the achievement of educational goals. Therefore over the years a number of researchers have developed different approaches to encourage peer tutoring, one of the remarkable one is Topping, Duran, \& Van (2016) emphasis on the need for peer tutoring.

Teaching algorithm and problem solving is a challenging task for lecturers and is an equally challenging task for the students to acquire the skill of problem solving and writing algorithm. Probably one of the most important skill a computer science student must possess is that of problem solving, another desirable and encouraged skill in a computer science student is that of the ability to think creatively. The biggest challenge that teachers and students of Computer Sciences and Mathematics face as beginners are the complications related to teaching and learning to write algorithms. Currently popular research methodology like Problem Based Learning (PBL) and Enquiry Based Learning (EBL) are employed to develop better problem solving and creativity skills for the students in the classroom (Rasool \& Chaudhry, 2012). Institutes have also recently started dabbling with possibility of inculcating peer tutoring in these subjects to enhance students' problem-solving and algorithm development abilities. Peer tutoring is beneficial in problem solving and algorithm development domains, as it enables sharing of ideas, social construction of knowledge, and address common misconceptions through peer interactions (Schoenfeld, 2016). Moreover, researchers are also introducing several support systems such as ITS (Intelligent Tutoring Systems), Adaptive Collaborative Learning Support (ACLS) and APTA (Adaptive Peer Tutoring Assistant) to help students with mathematics and problem solving in high school and university levels (Walker, Rummel, \& 
Koedinger, 2014).

The main aim of this research is to study the impact of peer tutoring as compared to only classroom tutoring on problem solving and algorithm development skills of higher education students in Computer Sciences.

\section{Literature Review}

\section{An Introduction to the Challenging Nature of Higher Education, Especially Computer Sciences (Problem Solving and Algorithm Development)}

The course content of computer science is challenging as it involves complex tasks such as programming, algorithm and system development and artificial intelligence (AI). These subjects require imparting knowledge in the right way, i.e. to not only make them theoretically sound through conceptual understandings but to also develop their technical and practical skills. The main aim of the course should be to foster a mechanism to ensure workplace success of the students.Teaching algorithm and problem solving to students is a challenging task for teachers and is an equally challenging task for the students to acquire the skill of problem solving and writing algorithm (Rasool \& Chaudhry 2012). Teaching is comprehended as a process of working cooperatively with students to encourage them to gather a better understanding. While teaching, a teacher must find out about the problems and misunderstandings that the students are facing (Gulatee \& Combes, 2006). Popular research methods are enabled through Enquiry Based Learning (EBL) and Problem Based Learning (PBL) to develop problem solving and creativity skills of students.

Classroom teaching does not encourage critical thinking skills for problem solving. It does not focus on larger concepts needed for problem solving and algorithm development. A teacher has a lot of things to teach but within the allotted time, with little or no interaction from the side of the students. This becomes problematic because the student learns only passively, which can hinder the student's learning process, as he can have a difficult time in staying focused. Newer learning methods like peer tutoring is a more simulative method where students can manipulate and work in groups to learn the lesson (Outhred \& Chester, 2010).There are other shortcomings of classroom teaching as well, in respect of problem solving and algorithm development. One of them is that the student is focused on noting down the points said by the teacher rather than trying to understand the concept. Due to this, they lack the ability to grasp key ideas and concepts of problem solving and failed in lesson objectives. Another shortcoming is that there is not much time left for practicing the concepts learned in class (Walker et al. 2014). Furthermore, many students might get stuck while doing problem sets at home (Buraphadeja \& Kumnuanta, 2011). Moreover, in a class of a huge number of students it becomes very difficult for a lecturer to provide one-to one attention to each student. In such a situation peer tutoring is a feasible option through which weaker students can perform better if provided with one to one interaction. Some students can perform 
excellently with a little help from their peer tutors (Adams, Kaczmarczyk, Picton, \& Demian, 2006). Most important role here is that of the professor. The professor designs the assignments and structure of the activities and corresponding instructions that the tutor and the tutee has to follow. This design will determine and define learning and the process of learning. The design and management of learning experiences is not a diminished role or one about which teachers need to feel guilty. It requires sophisticated teaching expertise (Weimer, 2017).

\section{Advantages, Applicability and Challenges of Peer Tutoring}

One of the biggest advantages of peer tutoring is academic achievement; the benefit is two-fold: not only does the tutor impart knowledge in the tutee, but he/she also enables self-learning in the teaching process. Peer tutors are challenged to use and hone their creativity and critical thinking skills to help tutees make logic of new matter introduced by the teacher. Students being tutored can ask questions to ensure understanding which not only tests and develops the knowledge of the tutee but also the tutor(Comfort \& McMahon, 2014).Students who receive peer tutoring generally attain perform due to enhanced interest and better attitude towards the subject.

According to the NEA, students undergoing peer tutoring experience personal development by extending a positive attitude towards learning and academia in general (Bierman \& Furman, 1981). Students who receive peer tutoring are less likely to fear or detest certain subjects, thus discouraging dropout greatly. Not only does it develop the knowledge of the tutee but also creates a feeling of self-worth in the tutee (Topping, Duran, \& Van Keer, 2016).

Self-confidence and self-reliance are also two other benefits of peer tutoring. Studying with someone their own age typically makes students feel more comfortable and relaxed, making them less hesitant towards learning. Peer tutors can narrate the problems faced by themselves during learning a concept or during solving a certain math problem and how they emerged from it. This helps the learner feel like the tutee is on the same level and that if the tutor did it, the tutee can do it too, thus greatly boosting self-reliance. Moreover, since the teacher's participation is negligible, students can feel self-confident and self-reliant as they tame complex problems on their own (Creswell, 2012).

However, the downside of peer tutoring is that organizing a peer tutoring activity can be a huge undertaking for a teacher. Firstly, peer tutors must themselves be trained at tutoring before they give sessions to their classmates. Secondly, organizing peer tutoring sessions may be problematic for the school administration as they need to make adjustments to their usual school timings. Lastly, it is an added burden for teachers in a number of ways. The peer tutoring sessions need to be routinely monitored to ensure that progress is being made (Cascio, 2017). A few other shortcomings include; the tutees may not learn as much because tutors are not as experienced as the teacher, and it does not promote positive relationship between the fellow students and the teacher if they are only working with one another.

With respect to the existing body of knowledge on peer tutoring benefits in 
problem solving and algorithm development, not many studies have been conducted. For instance, Nguyen (2013) studied how peer tutoring can be developed to successful instructional strategy to help low-performing students, and found that peer tutoring involves a number of activities which can be employed in isolation or cohesively to problem solving and algorithm development. Johnson (2016) researched how peer interaction brings out positive outcomes. According to him peer teaching is a far more instrumental strategy in which academically better performers can assume the role of instructors in the short term, especially in the case of problem solving and computer algorithm

Most of the studies about classroom reform and effective usage of technology does not focus on students leaving students out of the equation (Cuban, 1986; 2001; Zhao \& Frank, 2003).

Systematic studies of collaboration in open-ended, project-based environments are rare (Cohen, 1994)

Lab work and other tasks where students have to abide by rigid roles and protocols for working together similar to peer-tutoring sessions have been evaluated in the past by researchers (King, 1993; Swing \& Petersen, 1982). Most of these studies were conducted at K-12 teaching in the academic domain.

Peer tutoring is not a new concept, it is a very old form of collaborative or community action and has always taken place implicitly (Topping, 2005) but this method is more formalized and are becoming ever more popular in Higher education.

Vygotsky (1978) states that the concept of learning through peer tutoring is based on a social constructivist view of learning that focuses on students in learning, wherein students tutors their classmates through social interaction.

Rohrbeck, Ginsburg-Block, Fantuzzo, \& Miller (2003) finding suggest that one of the major advantages of peer learning in modern school systems is that it has allowed minority groups to integrate better, and the share their experience and thus there has been an increased likelihood of continued positive interact.

Peer assisted learning (PAL) is basically peer tutoring involving a senior student who is the tutor and a junior student who is the tutee. The tutor helps the junior student gain knowledge and skills, along with confidence and motivation. PAL is used across all levels of education. The seniors are at a better position to help the juniors as they themselves had been in that position sometime back.

Structured peer learning process will be beneficial for students and will save some time of the teaching staff especially during an era where university resources are limited and professor's time is distributed between teaching and performing advanced research and learning which is a major part of their professional development and also when universities are promoting research integrated teaching as a powerful tool in academia. Tutors here are students who not have power over the tutee by virtue of their position or responsibilities. In those research we are considering tutors who are in the same class as that of the tutee but who are doing well in the subject which is evaluated based on their performance in the class.

To facilitate successful peer learning, teachers may choose from an array 
of strategies (Christudason, 2003):

1. Buzz Groups: Students is divided into smaller groups of 4-5 students and are presented with a problem to solve. Following a discussion of around 20 minutes, the group leader presents the findings of their team to the class.

2. Affinity Groups: Here the groups of 4-5 students are assigned problem to work on outside class contact hours. They present their finding to the class the next tine the class meets.

3. Solution and Critic Groups: In this structure one of the sub-groups provide solution for a problem while another group 'critic group' will analyses the solution and offer their comments.

4. 'Solution and discussion': Towards the end of tutorial instruction session, students are required to write answers for a set of questions. The solutions are them discussed in the class with appropriate justification for the solution.

\section{Methodology}

In order to fulfil the objective of the research, the researcher carried out a primary study on 50 students pursuing a higher education degree in Computer Sciences. Problem solving and algorithms is taught to students doing computer science as an introductory course at most of the universities. The learning outcomes of the subject usually are that students should be able to create algorithms for solving simple problems and be able to determine the appropriate solution technique for a given problem. They should also should be able to demonstrate an understanding of the concepts of time and space complexity as applied to simple algorithms.

Survey method in the form of evaluation of students' test scores in different subjects was applied in two stages- before implementing working in pairs session, i.e. during mid-term, and after implementing peer tutoring, i.e. final term. Students who were weak in the subject were identified by the researcher based on results of tests conducted in the class. Working in pairs was facilitated in the class during the problem solving sessions. There a pair consists of a tutor and a tutee. Tutors were selected by the lecturer and trained to help and work as peer tutors. They were provided with material required for tutoring. The tutors were assigned one on one basis. Every student was assigned one tutor and a tutor was responsible for only one tutee. An activity diagram given in figure 1 explains the steps followed by the lecturer. 
Figure 1. Activity Diagram for Peer Tutoring Program

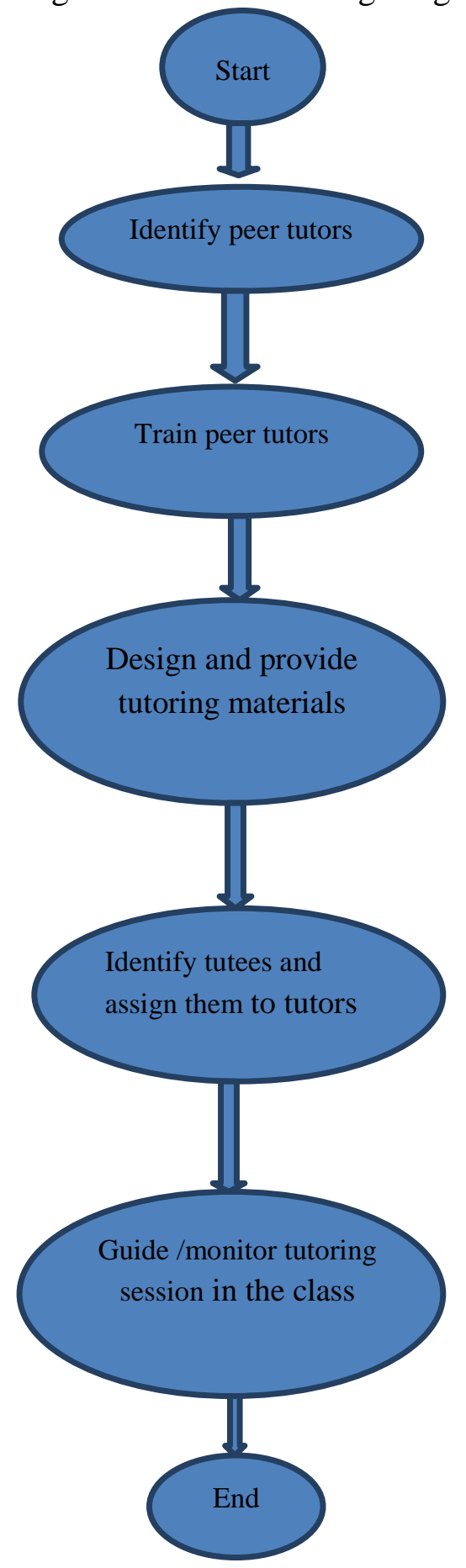

All students who took/gave were paired peer together belonged to the class were surveyed using purposive sampling method. The lecturer monitored and guided these sessions. In order to compare the benefits peer tutoring among the students studying computer science in higher education, $t$-test was run on SPSS software which was based on the results obtained by the students before and 
after peer tutoring.

This research has ethic approval from the university ethics committee. Student participation in the study was voluntary and anonymous. The data was used after consent was given by students to use their data for research and publication purposes. To meet the objective of the study the hypothesis was developed as below:

$\mathrm{H}_{0}$ : There is no significant difference between the marks obtained by the tutee and the tutor after classroom guided peer tutoring session.

$\mathrm{H}_{1}$ : There is significant difference between the marks obtained by the tutee and the tutor after classroom guided peer tutoring session.

\section{Data Analysis}

As the study included only quantitative analysis, the researcher used only inferential statistics to deduce the results. In inferential statistics technique paired sample t-test was conducted on the data of both terms individually. The paired-samples t-test is considered to be applied to compare two means for those situations where every participant is involved in both samples (Prophet StatGuide, 1997). Here, in the current study, the test was run on marks obtained in mid -term and final term. The participants were same at both point of time, therefore paired t-test was considered to be more relevant by the researcher. As per the assumptions of T-test the normality of the difference of paired data was checked for both terms.

Figure 1. Normality Distribution of Marks Difference for Exam before and Peer Tutoring Session for Tutee
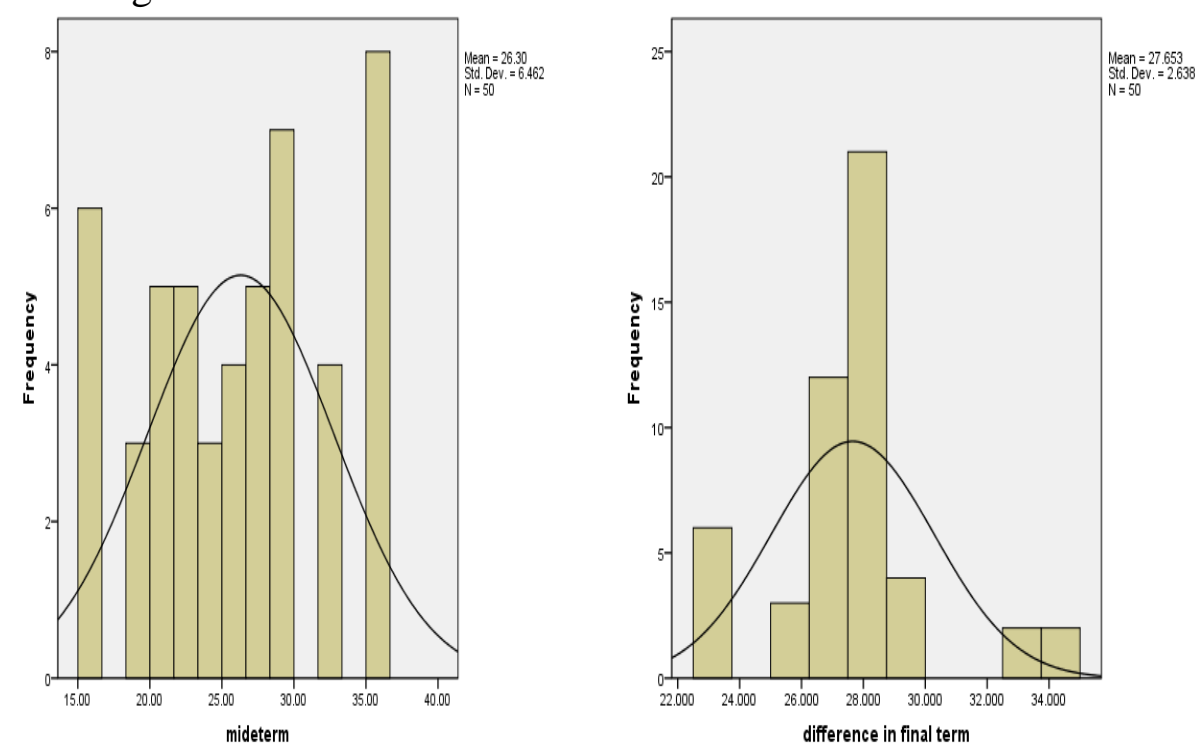

The difference of the marks is normally distributed for both the terms. After 
establishing the assumption of the normality, the researcher now attempts to explain the derived results.

\section{Analysis of Results for Mid -term Scores}

Table 1. Sample Statistics for Mid-term before Working in Pairs Session and Final Exam after Working In Pairs Session for Tutee

\begin{tabular}{|l|l|c|c|c|c|}
\hline \multicolumn{2}{|l|}{ Paired Samples Statistics } & Mean & N & $\begin{array}{c}\text { Std. } \\
\text { Deviation }\end{array}$ & $\begin{array}{c}\text { Std. Error } \\
\text { Mean }\end{array}$ \\
\hline Pair 1 & $\begin{array}{l}\text { mid-term term before } \\
\text { pair working session }\end{array}$ & 21.97000 & 50 & 5.710186 & .807542 \\
\hline $\begin{array}{l}\text { Final term after pair } \\
\text { working session }\end{array}$ & 69.13346 & 50 & 6.595986 & .932813 \\
\hline
\end{tabular}

In table 1 , the simple descriptive analysis has been represented. It can be deduced that there is a major difference between the mean scores of the marks obtained before implementing peer tutoring and after implementing peer tutoring in mid-term exams. Since $\mathrm{N}=50$, this implies that there is no missing value in the test variables.

Table 2.Correlation between the marks obtained before and after peer tutoring

\begin{tabular}{|l|l|c|c|c|}
\hline \multicolumn{2}{|l|}{ Paired Samples Correlations } & N & Correlation & Sig. \\
\hline Pair 1 & $\begin{array}{l}\text { mid-term } \\
\text { before and after peer tutoring }\end{array}$ & 50 & .548 & .000 \\
\hline
\end{tabular}

In table 2 it has been shown that there is a positive correlation between the marks obtained before implementing classroom guided peer tutoring and after classroom guided peer tutoring $(\mathrm{r}=.548, \mathrm{p}=.000)$. The $\mathrm{p}$-value less than .05 show that the relationship between both variables is significant. 
Table 3. Significance Test for the Difference Obtained Before and after Peer Tutoring Session for Exams for Tutee

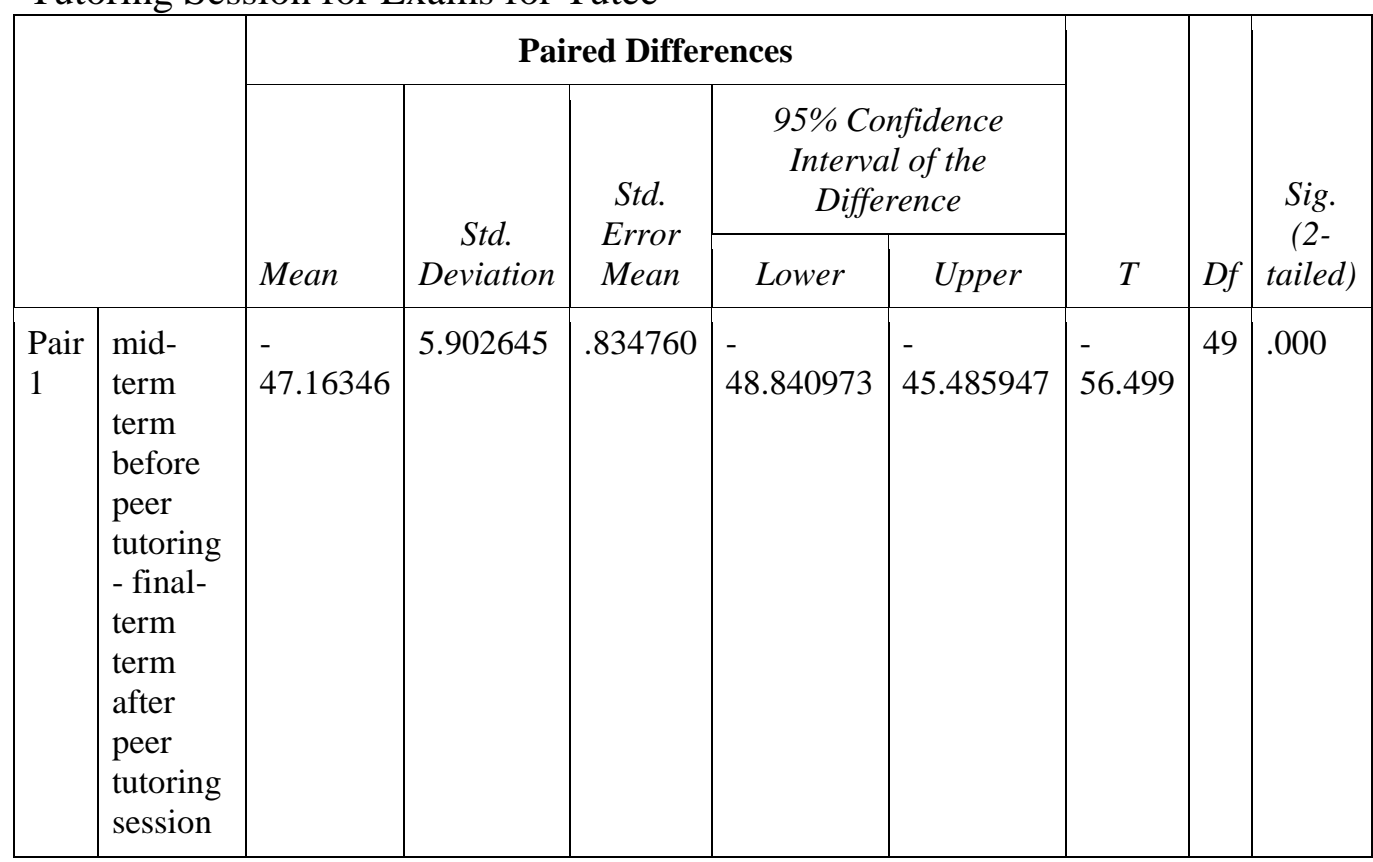

In the above table it can be seen that on average, scores obtained by the student after implementation of peer tutoring were 47 points higher than the scores obtained before applying peer tutoring on the students of computer science in mid-terms. On the basis of the obtained p-value .000<.05 and $\left(t_{49}=56.499\right)$, it can be inferred that there is a significant difference between the scores obtained before implementation of peer tutoring and after implementation peer tutoring on the students.

\section{Analysis of Results for Term Scores for Tutors}

Once the results for the mid-terms was obtained, in the next step the researcher moved to find out whether there is any significance difference after implementing pair working session in final terms on the respondents' academic performance.

Table 4. Sample Statistics for Mid-term and Final Term Before and After Peer Tutoring Session Respectively For Tutors

\begin{tabular}{|l|l|c|c|c|c|}
\hline \multicolumn{2}{|l|}{ Paired Samples Statistics } & Mean & N & \multicolumn{1}{|c|}{$\begin{array}{c}\text { Std. } \\
\text { Deviation }\end{array}$} & $\begin{array}{c}\text { Std. Error } \\
\text { Mean }\end{array}$ \\
\hline $\begin{array}{l}\text { Pair } \\
1\end{array}$ & Mid term before peer tutoring & 41.48000 & 50 & 3.957633 & .559694 \\
\hline & final term after peer tutoring & 48.01110 & 50 & 12.568360 & 1.777434 \\
\hline
\end{tabular}

From above table it has been deduced that there is a noticeable difference 
between the mean scores of the marks obtained by tutors before and after implementing peer tutoring sessions.

Table 5. Correlation between the Marks Obtained Before and After Peer Tutoring Sessions in the Exams

\begin{tabular}{|l|l|c|c|c|}
\hline \multicolumn{2}{|l|}{ Paired Samples Correlations } & N & Correlation & Sig. \\
\hline Pair 1 & $\begin{array}{l}\text { exam before peer tutoring \& } \\
\text { exam after peer tutoring }\end{array}$ & 50 & .560 & .000 \\
\hline
\end{tabular}

In table 5 it can be seen that with the values $(\mathrm{r}=.560, \mathrm{p}=.000)$, there is a significant positive association between the marks obtained before implementing peer tutoring and after implementing peer tutoring on the respondents in final term.

Table 6. Significance test for the Difference Obtained Before and After Peer Tutoring Session for Tutors

\begin{tabular}{|c|c|c|c|c|c|c|c|c|c|}
\hline \multirow{3}{*}{\multicolumn{2}{|c|}{$\begin{array}{l}\text { Paired Samples } \\
\text { Test }\end{array}$}} & \multicolumn{5}{|c|}{ Paired Differences } & \multirow[b]{3}{*}{$\mathrm{T}$} & \multirow[b]{3}{*}{ Df } & \multirow{3}{*}{$\begin{array}{l}\text { Sig. } \\
(2- \\
\text { tailed })\end{array}$} \\
\hline & & \multirow[b]{2}{*}{ Mean } & \multirow{2}{*}{$\begin{array}{l}\text { Std. } \\
\text { Deviation }\end{array}$} & \multirow{2}{*}{$\begin{array}{l}\text { Std. } \\
\text { Error } \\
\text { Mean }\end{array}$} & \multicolumn{2}{|c|}{$\begin{array}{l}95 \% \text { Confidence } \\
\text { Interval of the } \\
\text { Difference }\end{array}$} & & & \\
\hline & & & & & Lower & Upper & & & \\
\hline $\begin{array}{l}\text { Pair } \\
1\end{array}$ & $\begin{array}{l}\text { result } \\
\text { before } \\
\text { peer } \\
\text { tutoring }- \\
\text { exam } \\
\text { result after } \\
\text { peer } \\
\text { tutoring }\end{array}$ & - & 10.859835 & 1.535813 & 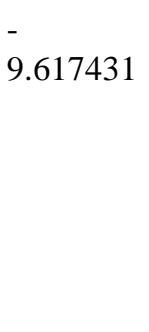 & - & - & 49 & .000 \\
\hline
\end{tabular}

On average, scores obtained by the students after implementation of peer tutoring session were at least 6 points higher than the scores obtained before applying peer tutoring on the students of computer science in the exam. On the basis of the obtained $\mathrm{p}$-value $<.05$ and $\left(\mathrm{t}_{49}=4.253\right)$, it can be deduced that again there is a significant difference between the scores obtained before implementation of the proposed sessions on the tutors.

\section{Result Summary}

It is evident from the result that there is significant difference (p-value < 0.05 ) between performance of the students before and after the peer tutoring sessions. This difference is seen in case of the performance of both the tutors and the tutees. Thus indicating that peer tutoring is more effective than working 
individually in a classroom among students of higher education pursuing computer science. This corresponds with the findings of Nguyen (2013) on students of computer sciences in higher education, showing that peering tutoring is more effective than the general way of tutoring as it helps to enhance the learning experience among the students.

Therefore, the researcher rejected null hypothesis $\left(\mathrm{H}_{1}\right)$ stating there is no significant difference between the marks obtained after and before peer tutoring sessions was facilitated has been rejected and accepted the alternate hypothesis $\left(\mathrm{H}_{0}\right)$.

Interesting finding is that the tutor has also benefited from peer tutoring sessions as improvement in the performance of all the peer tutors were clearly evident.

\section{Conclusion}

Peer tutoring is undeniably an effective strategy to improve students' learning abilities and their academic performance in a wide range of subjects. When it comes to computer sciences and complex problem solving, peer tutoring has been found to be a particularly useful tool in understanding and developing algorithms, to retain confidence, to promote academic success in the subject, and to build the student-teacher relationship. The role of instructor in a peer tutoring program includes selecting the tutors, providing them necessary training and material for tutoring, guiding tutoring sessions, identifying the tutees who need to undergo the peer tutoring sessions.

The results derived in the current study has established a positive relationship with the performance of the student in academics and peer tutoring by showing a clear difference in average marks obtained by the students after and before the implementation of peer tutoring. Form the findings of the study it can also be deduced that classroom guided peer tutoring proved to effectively complemented classroom teaching especially for subjects like problem solving and algorithms.

Both the tutor and the tutee have benefitted from this process. One of the most remarkable studies in the domain of computer sciences was conducted by Nguyen (2013) who concluded that working in pairs positively affects performance and reading achievement for students of all levels, accommodates diverse students to classroom, improves social and behavioral attitudes such as sense of control and self- responsibility in the students.

Also note that peer learning cannot replace the teacher. Professor will still be required to teach and students will still need professor's guidance. Similar to other instructional methods, peer learning will be beneficial when it is selected for a specific purpose, to solve a specific problem in a class and it needs to be carefully planned and monitored and evaluated.

Though this research focuses only on the improvement in performance through peer tutoring there are many other benefits to students involved in peer tutoring session that could be that could be studied as a part of future research. 
The findings from the current study can be generalized for the students pursuing other courses too as it has been universally opined that both students in the pair, students receive peer tutoring help and those who provide peer tutoring both succeed academically as it also fills any gaps they have in understanding the concepts in the classroom. Colleges should therefore encourage and facilitate peer tutoring session for students in subjects that could benefit from this method. Lecturers should proactively identify subject that could benefit from this method of teaching.

\section{References}

Adams, J., Kaczmarczyk, S., Picton, P., \& Demian, P., (2006). Problem solving and creativity in engineering: conclusions of a three year project involving reusable learning objects and robots. Engineering Education, 5(2), 4-17. Retrieved from http://bit.ly/2j5uDaF.

Bierman, L.K., \& Furman, W. (1981). Effects of Role and Assignment Rationale on Attitudes Formed During Peer Tutoring. Journal of educational psychology, 73(1), 33-40. Retrieved from http://bit.ly/2h8MqJC.

Buraphadeja, V., \& Kumnuanta, J., (2011). Enhancing the sense of community and learning experience using self-paced instruction and peer tutoring in a computerlaboratory course. Australasian Journal of Educational Technology, 27(8), 13381355.

Cascio, C., (2017). What Are Some Advantages \& Disadvantages of Peer Tutoring? Retrieved from http://bit.ly/2lWy7gn.

Chen, C., \& Liu, C., (2011). A case study of peer tutoring program in higher education. Research in Higher Education Journal, 11, 1-10.

Christudason, A. (2003). Peer Learning. CDTL, 37. Retrieved from https://nus.edu/2 Lw7Ij5.

Cohen, E.G. (1994). Restructuring the classroom: Conditions for productive small groups. Review of Educational Research, 64, 1-35.

Comfort, P., \& McMahon, J., (2014). The effect of peer tutoring on academic achievement. Journal of Applied Research in Higher Education, 6(1), 168-175. Retrieved from http://bit.ly/2Ad71CH.

Creswell, J., (2012). Educational research: Planning, conducting, and evaluating quantitative and qualitative research, New York: Pearson.

Cuban, L. (1986). Teachers and machines: The classroom uses of technology since 1920. New York: Teachers College Press.

Cuban, L. (2001). Oversold and Underused: Computers in Schools 1980-2000. Cambridge: MA: Harvard University Press.

Gulatee, Y., \& Combes, B. (2006). Identifying the Challenges in Teaching Computer Science Topics Online Proceedings of the EDU-COM 2006 International Conference. Engagement and Empowerment: New Opportunities for Growth in Higher Education, Edith Cowan University, Perth Western Australia, 22-24 November 2006,.206-213.

Horan, T., (2016). Create Your School Library Writing Center: Grades 7-12, Santa Barbara: ABC-CLIO.

Johnson, D., (2016). Student-Student Interaction: The Neglected Variable in Education. Sage: University of Minessota.

King, L. H. (1993). High and low achievers' perceptions of cooperative learning in 
two small groups. Elementary School Journal, 93, 399-416.

Nguyen, M. (2013). Peer tuto ring as a Strategy to Promote Academic Success. Duke University.

Outhred, T., \& Chester, A., (2010). The Experience of Class Tutors in a Peer Tutoring Programme: A Novel Theoretical Framework. Journal of Peer Learning, 3(3).

Prophet StatGuide, (1997). Do your data violate paired t test assumptions? Prophet. [web]. Retrieved from http://bit.ly/2lZXluH.

Rasool, G. \& Chaudhry, N. G., (2012). A Case Study on Improving Problem Solving Skills of Undergraduate Computer Science Students. World Applied Sciences Journal, 20(1), 34-39.

Rohrbeck, C. A., Ginsburg-Block, M. D., Fantuzzo, J. W., \& Miller, T. R. (2003). Peer-assisted learning interventions with elementary school students: A metaanalytic review. Journal of Educational Psychology, 95(2), 240-257.

Schoenfeld, A., (2016). Learning to think mathematically: Problem solving, metacognition, and sense making in mathematics. In Handbook for Research on Mathematics teaching and learning. New York: Macmillan.

Swing, S.R., \& Peterson, P.L. (1982). The relationship of student ability and small group interaction to student achievement. American Educational Research Journal, 19(2), 259-274.

Topping, K. (2005). Trends in Peer Learning. Educational Psychology, 25(6), 631-645

Topping, K., Duran, D., \& Van Keer, H. (2016). Using Peer Tutoring to Improve Reading Skills: A Practical Guide for Teachers, Routledge.

Vygotsky, L.S. (1978). Mind in Society. Cambridge, MA: Harvard University Press.

Walker, E., Rummel, N., \& Koedinger, K. (2014). Adaptive Intelligent Support to Improve Peer Tutoring in Algebra. International Journal of Artificial Intellegence Education, 24, 33-61.

Weimer, M., (2017). The Benefits of Peer Learning [Blog Post] Retrieved from http://bit.ly/2zguvLR.

Zhao, Y., \& Frank, K. (2003). Factors affecting technology uses in schools: An ecological perspective. American Educational Research Journal, 40(4), 807-840. 